\title{
IS WAGNER'S LAW APPLICABLE FOR FAST GROWING ECONOMIES? BRICS AND MATIK COUNTRIES
}

\author{
Bilal KARGI 1
}

DOI: 10.1515/tjeb-2016-0001

\begin{abstract}
This study investigates the causality relationship between public sector spending and economic growth. Although a relationship between these two variables is traditionally accepted, the direction of this causality relationship has widely been discussed. The relationship in which the increase of public sector spending moves together with the growth is called as Wagner's Law and it is examined through developing countries' data. As being developing country group, there is a huge literature about "BRICS countries". The unique contribution of this study is that it defines a new developing country group as "MATIK countries" and it analyzes BRICS and MATIK (BM) countries together. Therefore, the validity of Wagner's Law is tested on economic growth and public spending figures of these country groups which have significant population and economic size in world economy. As a result of Granger Causality Test for the period of 1961-2013, findings are obtained as Wagner's Law is not valid for majority of BM countries, which include 10 high growing economies. This conclusion is compared with other studies, which are conducted for developing countries.
\end{abstract}

Keywords: $\quad$ Wagner Law, BRICS and MATIK Country, Economic Growth.

JEL Classification: F43, H11, H50.

${ }^{1}$ Aksaray University, Sereflikochisar UTIYO, Department of Banking and Finance, Ankara, Turkey. 
Kargi, B. (2016).

Is Wagner's law applicable for fast growing economies? BRICS and MATIK countries

\section{Introduction}

Classical and Neo-Classical Economy are highly consistent on the subject of limiting and minimizing the public sector's activities during the growth processes. Keynes claimed that market mechanisms could not be balanced by itself, and public sector activities are necessary to remove these conditions after 1929 crisis. The share of public sector in the total economy had been increased till 1970s and growth processes had also included the public sector's activities after this hypothesis. Through 1980s this hypothesis of Keynesian economy was left so that the suggestions of neo-classical economy are started being accepted. However, the relationship between public sector activities and the economic growth has still being discussed. On the basis of the disagreements, there is the possibility that public sector's activities could have different effects depending on the development level of the countries which are examined. The second difference is public sector activities have different types. For example, public revenues are mostly depended on direct taxes in the developed countries while they are depended on indirect taxes in many of the developing countries. Different results can be reached through analysis due to these and these kinds of differences. The analyses which are based on the relationship between different public sectors activities and the growth could give different result similarly. The most commonly known relationship between the public spending which is one of the most important activities of the public sectors and the economic growth is brought forward by $A$. Wagner (1883) so that this is called as "Wagner's Law (Henrekson,1993).

Wagner associated this relationship to i) cultural and welfare improvement ii) administrative and preventing functions iii) spending toward to economic interruptions and firstly to natural monopolies (Bird, 1971; Tornton, 1999; Biehl, 1998). After Wagner, different many explanations are done for the increase of public spending. For example, the reason of the increase of public spending is associated with the governmental spending campaigns for low income voters and the source of the increase is seen in this point (Meltzer and Richard, 1981; Persson ve Tabellini, 1990). As a more general causalization, Masgrave (1969) commented that the increase rate of public spending would be much more than the rate of national income through the fact that education, health and public properties' rates are increased faster depending on the national income increase than shelter, food and clothing spending rates. There is a relationship between public spending and GDP increase per person in internal growth model of Barro (1990) and according to fixed contribution assumption of private sector and public services, the magnitude of public sector is effective in opposite direction on the growth rate. According to Barro (1991), public investments have positive effects on the growth rate due to raise the productivity while public spending affects the growth rate negatively.

DE GRUYTER OPEN
Timisoara Journal of Economics and Business | ISSN: 2286-0991 | www.tjeb.ro Year 2016 | Volume 9 | Issue 1 | Pages: 1 - 15 
Kargi, B. (2016).

Is Wagner's law applicable for fast growing economies? BRICS and MATIK countries

In the relationship between public spending and the economic growth, there are two main approaches which belong to Keynes and Wagner. The difference among Keynes and Wagner hypothesis is about causality direction (Chi-Hung and Chiehwen 2008). Keynes claimed that the increase of public spending will cause the growth while Wagner claimed that the growth will cause the increase of public spending. Both of those approaches are testes many times. Some of the studies gathered proofs about the invalidity of Wagner's Law (e.g. Ram (1986), Afxentiou and Serletis (1996); Wahab (2004)) as many studies found results about the validity of Wagner's Law. The main reason of this difference in the literature is stemmed from the fact that the perspectives and the explanatory variables were highly different in the conducted studies. Different arguments like the magnitude of the country (Alesina and Wacziarg, 1998); trade deficits (Rodrik, 1998); the differences of economic development levels (Easterly and Rebelo, 1993; Stein et al., 1999); political organization structures (Milesi Ferretti et al., 2002; Persson and Tabellini, 1999); the vulnerability level to economic uncertainties (Andres et al., 2008; Fatas and Mihov, 2001) could be effective on the results of the tests which are done for hypothesis. However in general, the relationship that Wagner claimed is more powerful in the developed countries and weaker in the developing countries (Akitoby et al., 2006).

The fact that population of the economies is constantly increasing and the increase of the welfare conditions of the individuals who are created by the economy's total growth will cause the increase of public spending by nature. The public spending which is about the welfare condition improvement will also determine the public revenues policy. Furthermore, public revenue is a function of the public spending as a budgeting principle. Moreover, an inconsistent spending policy will require increasing the tax revenues (Ram, 1987; Oxley, 1994). Therefore, this condition will create a pressure to direct and indirect tax payers and this can go further to smuggling (Barro, 1990; Roubini and Sala-i-Martin, 1995; Futagami, et al. 1993; Turnovsky, 1997). This pressure will narrow the individuals' spendable budgets and companies' profitability (Mishkin, 2011). Moreover, inflationist pressure will emerge due to the effects of taxes to manufacturing costs. In short, Wagner's Law is convenient to be discussed in all aspects of macroeconomic circle because it relates to cyclical relationship between public sector and the economic growth. I focus on the developing countries category in this study. There is a rich literature about the developing countries on the other hand due to the before mentioned reasons, different results are gathered. From this rich literature, the findings which belong to selected some studies which were conducted for selected country and country groups are provided in Table 1. As seen, these studies give some similar and some different results which relate to Wagner's Law.

This study is expected to make two important contributions to the literature. The first one is that this is the first study which examines BRICS economies for Wagner's Law. The second one is that Wagner's Law is tested as conducting analysis for each of two country groups by defining Mexico, Argentina, Turkey, Indonesia and Korea as "MATIK Countries" because

DE GRUYTER OPEN
Timisoara Journal of Economics and Business | ISSN: 2286-0991 | www.tjeb.ro Year 2016 | Volume 9 | Issue 1 | Pages: 1 - 15 
Kargi, B. (2016).

Is Wagner's law applicable for fast growing economies? BRICS and MATIK countries

there are big similarities in terms of qualitative aspects and characteristics with BRICS country group although there are quantitative differences among them. Afterwards, BRICS and MATIK countries will be shortly called as "BM".

Table 1. Selected Country and Country Groups for Wagner's Law

\begin{tabular}{|c|c|c|c|}
\hline Author(s) & Period & Country(s) & Conclusion \\
\hline $\begin{array}{l}\text { Afxentiou \& Serletis } \\
\text { (1996) }\end{array}$ & 1961-1991 & EU & Hypothesis is valid. \\
\hline Campo (1998) & $1980-1990$ & 100 World countries & $\begin{array}{l}\text { Positively associated with employment } \\
\text { expenses. }\end{array}$ \\
\hline Thornton (1999) & 19th cc & $\begin{array}{l}6 \text { Developed European } \\
\text { Countries }\end{array}$ & Valid with a powerful relationship. \\
\hline Islam (2001) & 1929-1996 & USA & Valid with a powerful relationship. \\
\hline Blackley (2003) & 1949-1998 & USA & $\begin{array}{l}\text { Spending other than interest is associated } \\
\text { with the growth. }\end{array}$ \\
\hline lyare \& Lorde (2004) & $1953-2000$ & Caribbean Countries & Hypothesis is valid. \\
\hline $\begin{array}{l}\text { Florio \& Colautti } \\
\text { (2005) }\end{array}$ & $1870-1990$ & $\begin{array}{l}\text { USA, U.K., France, } \\
\text { Germany, Italy }\end{array}$ & There is a relationship in the long run. \\
\hline Akitoby et al. (2006) & & 51 Developing Countries & It is co-integrated with $70 \%$ of the countries. \\
\hline $\begin{array}{l}\text { Narayan et al. } \\
\text { (2008) }\end{array}$ & $1990-2003$ & China States & $\begin{array}{l}\text { It is valid in Western States and is partly valid } \\
\text { in Eastern States. }\end{array}$ \\
\hline Ghartey (2008) & 1960-2005 & Jamaica & There is a relationship in the short run. \\
\hline Furuoka (2008) & 1970-2005 & Malaysia & It is co-integrated in the long run. \\
\hline Narayan (2008) & 1970-2002 & The Fiji Islands & There is Granger Causality in the long run. \\
\hline Rufael (2008) & 1964-2004 & 13 African Countries & $\begin{array}{l}\text { Partly double directed, partly single directed } \\
\text { and partly no causality. }\end{array}$ \\
\hline $\begin{array}{l}\text { Tang (2008); Tang } \\
\text { (2010) }\end{array}$ & $1960-2006$ & Malaysia & It is valid after 1985. \\
\hline Liu et al. (2008) & 1947-2002 & USA & $\begin{array}{l}\text { It is valid in the multiplied spending on the } \\
\text { other hand in the total spending Keynes in } \\
\text { valid. }\end{array}$ \\
\hline $\begin{array}{l}\text { Samudram \& Nair } \\
\text { (2008) }\end{array}$ & $1970-2004$ & Malaysia & $\begin{array}{l}\text { Double directed causality for health } \\
\text { spending; it is valid in the long run for the } \\
\text { other spending. }\end{array}$ \\
\hline Kalam \& Aziz (2009) & 1976-2007 & Bangladesh & It is valid in both long and short run. \\
\hline Dolenc (2009) & $1992-2007$ & Slovenia & Hypothesis is valid. \\
\hline Roy (2009) & 1950-1998 & USA & $\begin{array}{l}\text { Governmental spending has negative effects } \\
\text { on the growth. }\end{array}$ \\
\hline
\end{tabular}


Kargi, B. (2016).

Is Wagner's law applicable for fast growing economies? BRICS and MATIK countries

\begin{tabular}{|c|c|c|c|}
\hline Author(s) & Period & Country(s) & Conclusion \\
\hline $\begin{array}{l}\text { Lamartina \& Zaghini } \\
\text { (2010) }\end{array}$ & 1970-2006 & 23 OECD & $\begin{array}{l}\text { There is more powerful relationship in the } \\
\text { developing countries; It is also valid for the } \\
\text { developed countries however the rate is } \\
\text { lower than for the developing countries. }\end{array}$ \\
\hline Montiel (2010) & 1950-1999 & Mexico & There is Granger causality. It is valid. \\
\hline $\begin{array}{l}\text { Durevall \& } \\
\text { Henrekson (2011) }\end{array}$ & $1860-1970$ & Swedish and UK & The Law is not valid in the long run. \\
\hline Zheng et al. (2010) & $1952-2007$ & China & There is not any powerful proof. \\
\hline Zaman et al. (2011) & 1960-2009 & Pakistan & $\begin{array}{l}\text { There is no relationship between spending for } \\
\text { agriculture and the growth in the long run. }\end{array}$ \\
\hline $\begin{array}{l}\text { Brückner et al. } \\
\text { (2012) }\end{array}$ & $1960-2007$ & 43 World Country & $\begin{array}{l}\text { Hypothesis is valid although the parameters } \\
\text { are different for rich and poor countries. }\end{array}$ \\
\hline $\begin{array}{l}\text { Narayan et al. } \\
\text { (2012) }\end{array}$ & 1986-2009 & Indian States & $\begin{array}{l}\text { The Law is valid however, only capital } \\
\text { spending supports the growth. }\end{array}$ \\
\hline Magazzino (2012) & $1960-2008$ & Italy & There is Granger causality. \\
\hline Kumar et al. (2012) & $1960-2007$ & New Zealand & Granger causality is valid for the long run. \\
\hline Wu \& Lin (2012) & 1998-2006 & China & Hypothesis is not valid. \\
\hline ljeoma et al. (2012) & $1970-2010$ & Nigeria & Hypothesis is valid. \\
\hline Gurgul et al. (2012) & $2000-2008$ & Poland & $\begin{array}{l}\text { There is causality but it is valid in the } \\
\text { opposite direction. }\end{array}$ \\
\hline Akinlo et al (2013) & 1961-2009 & Nigeria & $\begin{array}{l}\text { It is valid as also associated with the } \\
\text { population. }\end{array}$ \\
\hline Kirchner (2013) & 1901-2009 & Australia & $\begin{array}{l}\text { It is valid in the long run and no valid in the } \\
\text { short run. }\end{array}$ \\
\hline $\begin{array}{l}\text { Bashirli \& Sabiroglu } \\
\text { (2013) }\end{array}$ & 2001-2010 & Oil-exporting countries & There is causality in both long and short run. \\
\hline $\begin{array}{l}\text { Grenade \& Wright } \\
\text { (2013) }\end{array}$ & $1980-2011$ & Caribbean Countries & It is valid because of political effects. \\
\hline Sakyi (2013) & $1980-2008$ & West African Countries & Hypothesis is valid \\
\hline
\end{tabular}

Goldman Sachs has used the abbreviation of BRIC (Brazil, Russia, India, and China) for the first time to mean "rapid developing economies" in 2001 (Singh, 2013). After the regional economic cooperation organization begin to increase in last 40 years, in the final period, BRIC economies became the main topic as structuring beyond the regional samples in 2006. These economies have partially become official with the meeting that was made by foreign affairs ministers of the 4 national rapid developing economies. Brazil, Russia, India and China leaders have reached a consensus for meeting once a year in order to discuss economical and political issues. So, some kind of unity that has formed with the initials (BRIC) of these 4 countries. In 2011, when South Africa was invited to the third meeting in 
Kargi, B. (2016).

Is Wagner's law applicable for fast growing economies? BRICS and MATIK countries

China, the group had a new addition and have been called BRICS ever since. In 2006, from the first meeting at a level of Foreign affairs ministers to the present meetings were made about foreign affairs, finance and economy, trade, agriculture, and health. The meetings have continued about science, technology, trade rivalry and national security. In 2011, in the third meeting, it reached a consensus about playing a central role for the world economy (Schmalz \& Ebenau, 2012). It expanded visions that BRICS economies probably will be the biggest economies of the world in by 2030 (Khan, 2011; Yao \& Liu, 2011).

Some abbreviations are generated for the rapid developing economies except BRICS. For example, the abbreviations such as Mexico, Argentina, Nigeria and Turkey (MANT); Poland, Indonesia, Korea and South Africa (PIKS); BRIC+Argentina (BRIC-A) are in question (Aggarwal, 2013; Aktan et al., 2009). I use (MATIK) abbreviation for Mexico, Argentina, Turkey, Indonesia and Korea in this study, and while I do my analysis through BRICS, I also do it for MATIK. Moreover, I include (BRICS+MATIK) into the analysis by combining these two rapidly developing country groups that generate a great majority of the world's population and economy. In addition, I include BRICS+MATIK economies into the analysis by comparing them with the world and the G-7 economies. According to January data of 2014, while world population is 7.145 billion, G-7 countries are 747.914 million; BRICS+MATIK countries population is 3.512 .958 million. Proportionately, BRICS+MATIK generate $49,16 \%$ of world population, and G-7 countries generate $10,46 \%$ of world population.

Public sector is very big economical category and it is consisted of a big range from stateowned enterprises (SOE) to public revenue and spending, fiscal or monetary policy. Each of the variables in this range has different effects on the growth. Public spending is one of the most effective functions of the public sector and different effects can exist depending on the spending qualifications.

There exist empirical findings about structural and R\&D based spending affects positively the growth processes while there are also some studies that depict the fact that social security spending has negative effects over the growth processes. The total population of BM countries as fast developing countries consist $49,16 \%$ of the world population and $26,46 \%$ of the world economy. BM economies which had $4,25 \%$ average growth rate (BRICS $3,7 \%$; MATIK $4,8 \%$ ) based on the period of $1962-2012$ and they consist $26,46 \%$ of the world economy through 2013. The growth rate of world economies was $3,45 \%$ through the period of 1962-2012; OECD countries' average growth rate was 3,13\% and G-7 countries average growth rate was 2,9 (Kargi, 2014). It is obvious that BM countries have a very big growth rate as comparing to other categories. Therefore, it is worth to examine the relationship between this big growth rate and public spending in BM economies as such a big economic category. There are many components which support BM countries this growth rate. An interesting research subject is whether public sector support and encourage this growth processes as one of those components or not.

DE GRUYTER OPEN
Timisoara Journal of Economics and Business | ISSN: 2286-0991 | www.tjeb.ro Year 2016 | Volume 9 | Issue 1 | Pages: 1 - 15 
Kargi, B. (2016).

Is Wagner's law applicable for fast growing economies? BRICS and MATIK countries

In short, UN country groups are fast developing economies and their growth processes should be examined through many aspects. They are also very convenient country groups to investigate the relationship between the growth and public spending which have been discussed through economy literature.

\section{Data and Methodology}

The growth and public spending data which belong to BM countries are obtained from UNCD and these are for the period of 1980-2012 (for Russia 1989-2013). The growth rate (g) depicts GDP increase. The variable of total public spending (s) is the rate of countries' public spending to GDP. Therefore, the direction and the degree of the relationship between public spending and the growth could be tested. Seasonal tests were not needed due to the fact that series are annual data.

The main hypothesis which is tested through the study is "there is causality from economic growth to public spending." This causality relationship could have the directions as Keynes and Wagner assumed. This study focus on the direction of the relationship between the growth and public spending, moreover the long term based relationship between the variables are tested. Accordingly, the secondary hypothesis is "economic growth and public spending is co-integrated in the long run.". Granger causality test (1969) is used for testing the first hypothesis. DickeyFuller (1979); Phillips-Perron (1988) and KPSS (1992) unit root tests are used to verify the condition of that series must be constant for Granger causality. (The error correction model is also applied to sustain the short term balance and to eliminate data loss which is happened because the first differences are taken in case of that the series are not constant in their level values.) Engle-Granger (1987) two phased co-integration test is applied to test the second hypothesis.

\section{Empirical Analysis and Results}

The results related to three different unit root tests which are done in order to test whether the series are constant or not are shown in Table 2. The columns in Table 2, which are shown as " $\Delta$ ", are the test results which are obtained when the first differences of the series are taken.

The series are not constant according to each of three tests results so that their first differences are taken to set them constant. When comparing the critic values which are shown inside of the brackets with the test statistics under the column which is depicted by $\Delta^{\prime \prime \prime}$ symbol in Table 2 , they verify the series become constant as taking the first differences. 
Kargi, B. (2016).

Is Wagner's law applicable for fast growing economies? BRICS and MATIK countries

Table 2. ADF, PP and KPSS Unit Root Tests (No Intercept and Trend)

\begin{tabular}{|c|c|c|c|c|c|c|}
\hline & ADF & $\mathrm{ADF} \Delta$ & PP & $\mathrm{PP} \Delta$ & KPSS & KPSS $\triangle$ \\
\hline Brazil & $\begin{array}{l}-1.965735 \\
(-2.611094) \\
0.426030 \\
(-2.610192)\end{array}$ & $\begin{array}{l}-10.80296 \\
(-2.611094) \\
-8.518785 \\
(-2.611094)\end{array}$ & $\begin{array}{l}-2.818729 \\
(-2.610192) \\
0.433711 \\
(-2.610192)\end{array}$ & $\begin{array}{l}-14.51167 \\
(-2.611094) \\
-8.494389 \\
(-2.611094)\end{array}$ & $\begin{array}{l}0.444875 \\
(0.739000) \\
0.676525 \\
(0.739000)\end{array}$ & $\begin{array}{l}0.191034 \\
(0.739000) \\
0.380891 \\
(0.739000)\end{array}$ \\
\hline Russia & $\begin{array}{l}-2.186479 \\
(-2.669359) \\
-0.342274 \\
(-2.664853) \\
\end{array}$ & $\begin{array}{l}-6.709351 \\
(-2.674290) \\
-5.817922 \\
(-2.674290)\end{array}$ & $\begin{array}{l}-2.186479 \\
(-2.669359) \\
-0.248306 \\
(-2.664853)\end{array}$ & $\begin{array}{l}-7.228242 \\
(-2.674290) \\
-7.277827 \\
(-2.669359)\end{array}$ & $\begin{array}{l}0.398784 \\
(0.739000) \\
0.103066 \\
(0.739000)\end{array}$ & $\begin{array}{l}0.140323 \\
(0.739000) \\
0.500000 \\
(0.739000)\end{array}$ \\
\hline India & $\begin{array}{l}-0.960811 \\
(-2.612033) \\
0.952678 \\
(-2.610192)\end{array}$ & $\begin{array}{l}-9.436515 \\
(-2.612033) \\
-6.162140 \\
(-2.612033)\end{array}$ & $\begin{array}{l}-2.308628 \\
(-2.610192) \\
0.922685 \\
(-2.610192)\end{array}$ & $\begin{array}{l}-29.90033 \\
(-2.611094) \\
-6.282721 \\
(-2.611094)\end{array}$ & $\begin{array}{l}0.835311 \\
(0.739000) \\
0.764507 \\
(0.739000)\end{array}$ & $\begin{array}{l}0.036225 \\
(0.739000) \\
0.164603 \\
(0.739000)\end{array}$ \\
\hline China & $\begin{array}{l}-1.623503 \\
(-2.612033) \\
-0.296800 \\
(-2.610192)\end{array}$ & $\begin{array}{l}-8.512389 \\
(-2.611094) \\
-2.939981 \\
(-2.617364)\end{array}$ & $\begin{array}{l}-2.676276 \\
(-2.610192) \\
-0.292489 \\
(-2.610192)\end{array}$ & $\begin{array}{l}-9.127530 \\
(-2.611094) \\
-8.408039 \\
(-2.611094)\end{array}$ & $\begin{array}{l}0.503965 \\
(0.739000) \\
0.422569 \\
(0.739000)\end{array}$ & $\begin{array}{l}0.275366 \\
(0.739000) \\
0.095488 \\
(0.739000)\end{array}$ \\
\hline S. Africa & $\begin{array}{l}-2.427359 \\
(-2.610192) \\
1.958645 \\
(-2.610192)\end{array}$ & $\begin{array}{l}-7.430080 \\
(-2.612033) \\
-5.900289 \\
(-2.611094)\end{array}$ & $\begin{array}{l}-2.097226 \\
(-2.610192) \\
2.371291 \\
(-2.610192)\end{array}$ & $\begin{array}{l}-20.20259 \\
(-2.611094) \\
-5.856699 \\
(-2.611094)\end{array}$ & $\begin{array}{l}0.390915 \\
(0.739000) \\
0.913332 \\
(0.739000)\end{array}$ & $\begin{array}{l}0.500000 \\
(0.739000) \\
0.153946 \\
(0.739000)\end{array}$ \\
\hline Mexico & $\begin{array}{l}-2.965035 \\
(-2.610192) \\
0.897964 \\
(-2.610192)\end{array}$ & $\begin{array}{l}-7.662459 \\
(-2.612033) \\
-6.332757 \\
(-2.611094)\end{array}$ & $\begin{array}{l}-2.797686 \\
(-2.610192) \\
0.712010 \\
(-2.610192)\end{array}$ & $\begin{array}{l}-27.83502 \\
(-2.611094) \\
-6.404030 \\
(-2.611094)\end{array}$ & $\begin{array}{l}0.636322 \\
(0.739000) \\
0.708392 \\
(0.739000)\end{array}$ & $\begin{array}{l}0.433913 \\
(0.739000) \\
0.088749 \\
(0.739000)\end{array}$ \\
\hline Arg & $\begin{array}{l}-5.007378 \\
(-2.610192) \\
-0.201195 \\
(-2.610192)\end{array}$ & $\begin{array}{l}-8.851651 \\
(-2.612033) \\
-8.446579 \\
(-2.611094)\end{array}$ & $\begin{array}{l}-5.032982 \\
(-2.610192) \\
0.325031 \\
(-2.910192)\end{array}$ & $\begin{array}{l}-33.23015 \\
(-2.611094) \\
-8.882743 \\
(-2.611094)\end{array}$ & $\begin{array}{l}0.100000 \\
(0.739000) \\
0.220561 \\
(0.739000)\end{array}$ & $\begin{array}{l}0.467940 \\
(0.739000) \\
0.180513 \\
(0.739000)\end{array}$ \\
\hline Turkey & $\begin{array}{l}-2.332681 \\
(-2.611094) \\
0.783708 \\
(-2.610192)\end{array}$ & $\begin{array}{l}-8.629630 \\
(-2.612033) \\
-7.096444 \\
(-2.611094)\end{array}$ & $\begin{array}{l}-3.805554 \\
(-2.610192) \\
0.715281 \\
(-2.610192)\end{array}$ & $\begin{array}{l}-25.51235 \\
(-2.611094) \\
-7.117852 \\
(-2.611094)\end{array}$ & $\begin{array}{l}0.109445 \\
(0.739000) \\
0.540079 \\
(0.739000)\end{array}$ & $\begin{array}{l}0.084257 \\
(0.739000) \\
0.085468 \\
(0.739000)\end{array}$ \\
\hline Indonesia & $\begin{array}{l}-2.356792 \\
(2.610192) \\
-0.731719 \\
(-2.610192)\end{array}$ & $\begin{array}{l}-7.925829 \\
(-2.612033) \\
-12.28126 \\
(-2.611094)\end{array}$ & $\begin{array}{l}-2.356792 \\
(-2.610192) \\
-0.697999 \\
(-2.610192)\end{array}$ & $\begin{array}{l}-19.96889 \\
(-2.611094) \\
-13.12983 \\
(-2.611094)\end{array}$ & $\begin{array}{l}0.118233 \\
(0.739000) \\
0.132241 \\
(0.739000)\end{array}$ & $\begin{array}{l}0.233555 \\
(0.739000) \\
0.112215 \\
(0.739000)\end{array}$ \\
\hline Korea Rep. & $\begin{array}{l}-0.682819 \\
(-2.614029) \\
-0.393107 \\
(-2.610192)\end{array}$ & $\begin{array}{l}-6.598312 \\
(-2.614029) \\
-7.014346 \\
(-2.611094)\end{array}$ & $\begin{array}{l}-1.652125 \\
(-2.610192) \\
-0.364457 \\
(-2.610192)\end{array}$ & $\begin{array}{l}-22.62237 \\
(-2.611094) \\
-7.032467 \\
(-2.611094)\end{array}$ & $\begin{array}{l}0.642071 \\
(0.739000) \\
0.579199 \\
(0.739000)\end{array}$ & $\begin{array}{l}0175838 \\
(0.739000) \\
0.181389 \\
(0.739000)\end{array}$ \\
\hline
\end{tabular}

Note: For each country, the values in the upper lines belong to (g) variable and italic values in the lower lines belong to (s) variable. The values inside the brackets are test critical values with $1 \%$ significance level.

The series, which became constant from the same degree, are applied to long term cointegration test for each country. The results of Engle-Granger test which is used for this are shown in Table 3. The parameters and t-statistics which belong to regression equations that are 
Kargi, B. (2016).

Is Wagner's law applicable for fast growing economies? BRICS and MATIK countries

built among the (g) and (s) variables for each country are illustrated in the table. The error term (u) which are obtained from the regressions are applied to unit root tests (ADF and PP) again. The condition of that error terms must be constant is matched. This result is obtained when the test statistics which are obtained for error terms are compared the critical values which are shown inside the brackets.

Table 3. Engle - Granger Co-integration Test

\begin{tabular}{|c|c|c|c|c|}
\hline Equation & Coefficient & t-Stat. & $\mathrm{u} \rightarrow \mathrm{ADF}$ & $\mathrm{u} \rightarrow \mathrm{PP}$ \\
\hline Brazil & -0.347847 & -0.755665 & $\begin{array}{l}-10.78238 \\
(-3.565430)\end{array}$ & $\begin{array}{l}-14.23231 \\
(-3.565430)\end{array}$ \\
\hline Russia & -0.205576 & -0.349285 & $\begin{array}{l}-6.729700 \\
(-3.769597)\end{array}$ & $\begin{array}{l}-7.508552 \\
(-3.769597)\end{array}$ \\
\hline India & -2.487205 & -2.137474 & $\begin{array}{l}-6.307663 \\
(-3.574446)\end{array}$ & $\begin{array}{l}-21.36689 \\
(-3.565430)\end{array}$ \\
\hline China & 2.282701 & 1.583141 & $\begin{array}{l}-7.761992 \\
(-3.565430)\end{array}$ & $\begin{array}{l}-8.040614 \\
(-3.565430)\end{array}$ \\
\hline S. Africa & -1.188256 & -2.568981 & $\begin{array}{l}-7.760996 \\
(-3.268308)\end{array}$ & $\begin{array}{l}-37.72546 \\
(-3.565430)\end{array}$ \\
\hline Mexico & -0.501953 & -0.562508 & $\begin{array}{l}-7.750828 \\
(-3.568308)\end{array}$ & $\begin{array}{l}-24.06932 \\
(-3.565430)\end{array}$ \\
\hline Argentina & -1.163592 & -2.597371 & $\begin{array}{l}-9.743392 \\
(-3.565430)\end{array}$ & $\begin{array}{l}-18.59121 \\
(-3.565430) \\
\end{array}$ \\
\hline Turkey & -0.031531 & -1.579511 & $\begin{array}{l}-6.856248 \\
(-3.565430)\end{array}$ & $\begin{array}{l}-6.859222 \\
(-3.565430)\end{array}$ \\
\hline Indonesia & 0.776320 & 1.547725 & $\begin{array}{l}-8.061431 \\
(-3.568308)\end{array}$ & $\begin{array}{l}-31.66495 \\
(-3.565430)\end{array}$ \\
\hline Korea Rep. & -1.338549 & -2.493665 & $\begin{array}{l}-6.577396 \\
(-3.574446)\end{array}$ & $\begin{array}{l}-31.70071 \\
(-3.565430)\end{array}$ \\
\hline
\end{tabular}

Note: The values in brackets and under the coefficients are Standard Deviation Values. The values in brackets and under ADF, PP and KPSS test statistics are the critical values for $5 \%$ significance level.

Table 4 tests the causality relationship between (g) and (s) variables. Granger causality test results are done through 5\% significance level and 2 delay. Ho hypothesis is "the variable of (s) is not Granger reason of the variable of (g)". The alternative hypothesis is as Wagner brought forward "(s) is the reason of (g)". 
Kargi, B. (2016).

Is Wagner's law applicable for fast growing economies? BRICS and MATIK countries

Table 4. Granger Causality Test

\begin{tabular}{|c|c|c|c|c|}
\hline & Hypotheses & Chi-sq & Prob. & Result \\
\hline \multirow{2}{*}{ Brazil } & Wagner & 0.560312 & 0.7557 & (s) is not the reason of (g). \\
\hline & Keynes & 1.379583 & 0.5017 & (g) is not the reason of (s). \\
\hline \multirow{2}{*}{ Russia } & Wagner & 4.243775 & 0.1198 & (s) is not the reason of (g). \\
\hline & Keynes & 1.132042 & 0.5678 & (g) is not the reason of (s). \\
\hline \multirow{2}{*}{ India } & Wagner & 0.061012 & 0.9700 & (s) is not the reason of (g). \\
\hline & Keynes & 2.883540 & 0.2365 & (g) is not the reason of (s). \\
\hline \multirow{2}{*}{ China } & Wagner & 4.421365 & 0.1096 & (s) is not the reason of $(\mathrm{g})$. \\
\hline & Keynes & 2.369751 & 0.3058 & (g) is not the reason of (s). \\
\hline \multirow{2}{*}{ S. Africa } & Wagner & 6.852868 & 0.0325 & (s) is the reason of (g). \\
\hline & Keynes & 0.539072 & 0.7637 & (g) is not the reason of (s). \\
\hline \multirow{2}{*}{ Mexico } & Wagner & 2.489833 & 0.2880 & (s) is not the reason of (g). \\
\hline & Keynes & 0.274476 & 0.8718 & (g) is not the reason of (s). \\
\hline \multirow{2}{*}{ Argentina } & Wagner & 1.548467 & 0.4611 & (s) is not the reason of $(\mathrm{g})$. \\
\hline & Keynes & 10.44791 & 0.0054 & (g) is the reason of (s). \\
\hline \multirow{2}{*}{ Turkey } & Wagner & 8.500288 & 0.0143 & (s) is the reason of (g). \\
\hline & Keynes & 0.240998 & 0.8865 & (g) is not the reason of (s). \\
\hline \multirow{2}{*}{ Indonesia } & Wagner & 0.458962 & 0.7949 & (s) is not the reason of (g). \\
\hline & Keynes & 2.826529 & 0.2433 & (g) is not the reason of (s). \\
\hline \multirow{2}{*}{ Korea Rep. } & Wagner & 1.482568 & 0.4765 & (s) is not the reason of (g). \\
\hline & Keynes & 7.593163 & 0.0224 & (g) is the reason of (s). \\
\hline
\end{tabular}

Note: For Wagner, Ho: (s) is not the Granger reason of (g). H1: (s) is the Granger reason of (g). Ho is declined for prob. < 0.05. Ho is accepted when prob. >0.05. For Keynes, Ho: (g) is not the Granger reason of (s). H1: (g) is the Granger reason of (s). Ho is declined for prob. $<0.05$. Ho is accepted when prob. $>0.05$.

Whether there is causality from (g) to (s) is also tested in Table 4. The hypothesis that Keynes claimed as " $(\mathrm{g})$ is the reason of (s)." is the $\mathrm{H} 1$ hypothesis. Therefore tested Ho hypothesis is "the variable of $(\mathrm{g})$ is not the reason of the variable of $(\mathrm{s})$ ".

\section{Conclusions}

BM countries are growing fast. However, except China and Korea they are not the countries which can have high capital amounts. Therefore BM countries are vulnerable to external shocks. At the same time, public sector's effects over country economies are dominant. Political processes can affect the economy conjecture intensely. BM countries' growth performance and public spending are co-integrated in the long run depend on the long term 
Kargi, B. (2016).

Is Wagner's law applicable for fast growing economies? BRICS and MATIK countries

tests that are shown in this study. Therefore, there is co-integration between (g) and (s) in the long run for all BM countries according to the results of Table 3.

However, Wagner Hypothesis is not valid for many of BM countries according to 1961-2013 data. There is causality for only South Africa, Argentina and Turkey in the long run when Table-4 is analyzed. Through these causalities, Wagner's Rule is applicable for South Africa and Turkey while Keynes's hypothesis is valid for Argentina. This result will require the examination in terms of qualitative aspects of economic growth in addition to its quantitative aspects.

As a result of this condition, it could be said that public spending is not efficient spending that support the economy. Causality between public spending and the growth is not found although economic growth is achieved through inefficient spending. On the other hand, a more widely research should be conducted about public spending types in order to determine the public spending which support economic growth in the long run.

\section{References}

Afxentiou, P. C. \& Serletis, A. (1996). Government expenditures in the European Union: Do they converge or follow Wagner's Law, International Economic Journal, 10, 33-47. DOI: $10.1080 / 10168739600000003$

Aggarwal, R. (2013). Adjusting to BRICs in Glass Houses: Replacing Obsolete Institutions and Business Models, Thunderbird International Business Review, 55(1), 37-54. DOI: $10.1002 /$ tie. 21522

Akinlo, E. E. (2013). Government spending and national income nexus for Nigeria, Global Journal of Business Research, 7(1), 33-41.

Akitoby, B., Clements, B., Gupta, S. \& Inchauste, G. (2006). Public spending, voracity, and Wagner's Law in developing countries, European Journal of Political Economy, 22(4), 908-928. DOI: 10.1016/j.ejpoleco.2005.12.001

Aktan, B., Mandaci, P. E., Kopurlu, B. S. \& Ersener, B. (2009). Behavior of Emerging Stock Markets in The Global Financial Meltdown: Evidence From BRIC-A. African Journal of Business Management, 3(9), 396-404. DOI: 10.5897/AJBM09.121

Alesina, A. \& Wacziarg, R. (1998). Openness, country size and government, Journal of Public Economics, 69(3), 305-321. DOI: 10.1016/S0047-2727(98)00010-3

Andre's, J., Domenech, R. \& Fatas, A. (2008). The stabilizing role of government size, Journal of Economic Dynamics and Control, 32, 571-593. DOI: 10.1016/j.jedc.2007.02.006

Barro, R. (1990). Government spending in a simple model of endogenous growth, Journal of Political Economy, 98(5), S103-S125. DOI: $10.1086 / 261726$

Barro, R. (1991). Economic growth in a cross section countries, Quarterly Journal of Economics, 106(2), 407-443. DOI: $10.2307 / 2937943$

Bashirli, S. \& Sabiroglu, I. M. (2013). Testing Wagner's Law in an oil-exporting economy: The case of Azerbaijan, Transition Studies Review, 20(3), 295-307. DOI: 10.1007/s11300$\underline{013-0292-4}$

DE GRUYTER OPEN 
Kargi, B. (2016).

Is Wagner's law applicable for fast growing economies? BRICS and MATIK countries

Biehl, D. (1998). Wagner's Law: An introduction to and a translation of the last version of Adolph Wagner's text of 1911, Public Finance, 53(1), 102-111.

Bird, R. M. (1971). Wagner's of Law' of expanding state activity, Public Finance, 26, 1-26.

Blackley, P. R. (2003). Price versus income effects as sources of growth in government's share of GDP, Public Finance Review, 31(3), 241-262. DOI: 10.1177/1091142103031003002

Brückner, M., Chong, A. \& Gradstein, M. (2012). Estimating the permanent income elasticity of government expenditures: Evidence on Wagner's Law based on oil price shocks, Journal of Public Economics, 96(11-12), 1025-1035. DOI: 10.1016/i.jpubeco.2012.08.002

Campo, S. S. (1998). Government employment and pay: The global and regional evidence, Public Administration and Development, 18(5), 457-478. DOI: 10.1002/(SICI)1099162X(199812)18:5<457::AID-PAD40>3.0.CO;2-P

Chi-Hung, L. L. \& Chiehwen E. H. (2008). The association between government expenditure and economic growth: Granger causality test of US data, 1947-2002, Journal of Public Budgeting, Accounting, and Financial Management, 20(4), 439-452.

Dickey, D. A. \& Fuller, W. A. (1979). Distribution of the Estimators of Autoregressive Time Series with a Unit Root, Journal of the American Statistical Association, 74(366), 427-431. DOI: $10.2307 / 2286348$

Dolenc, P. (2009). Wagner's Law is still applicable: Empirical evidence for Slovenia, Nase Gospodarstvo, 55(5-6), 68-76.

Durevall, D. \& Henrekson, M. (2011). The futile quest for a grand explanation of long-run government expenditure, Journal of Public Economics, 95(7-8), 708-722. DOI: $10.2139 /$ ssrn.1539425

Easterly, W. \& Rebelo, S. (1993). Fiscal policy and economic growth: An empirical investigation, Journal of Monetary Economics, 32(3), 417-458. DOI: 10.1016/03043932(93)90025-B

Engle, R. F., \& Granger, C. W. J. 1987. Co-integration and errors correction: Representation, estimation, and testing, Econometrica, 55, 251-276.

Fatas, A. \& Mihov, I. (2001). Government size and automatic stabilizers: International and international evidence, Journal of International Economics, 55(2), 3-28. DOI: $10.2307 / 1913236$

Florio, M. \& Colautti, S. (2005). A logistic growth theory of public expenditures: A study of five country over 100 years, Public Choice, 122(3), 355-393. DOI: 10.1007/s11127005-3900-y

Furuoka, F. (2008). Wagner's Law in Malaysia: A New empirical evidence, The Icfai University Journal of Applied Economics, 7, 33-43.

Futagami, K., Morita, Y. \& Shibata A. (1993). Dynamic analysis of an endogenous growth model with public capital, Scandinavian Journal of Economics, 95(4), 607-625. DOI:: $10.2307 / 3440914$

Ghartey, E. E. (2008). The budgetary process and economic growth: Empirical evidence of the Jamaican economy, Economic Modelling, 25(6), 1128-1136. DOI: 10.1016/j.econmod.2008.02.004

Granger, C. W. J. (1969). Investigating causal relations by econometric models and crossspectral methods, Econometrica, 373), 424-438. DOI: 10.2307/1912791

Grenade, K. \& Wright, A. (2013). Public spending in selected Caribbean countries: Testing Wagner's Law and the Ratchet Hypothesis, Public Finance Review, 42(4), 1-24. DOI: $\underline{10.1177 / 1091142113499395}$ 
Kargi, B. (2016).

Is Wagner's law applicable for fast growing economies? BRICS and MATIK countries

Gurgul, H., Lach, L. \& Mestel, R. (2012). The relationship between budgetary expenditure and economic growth in Poland, Central European Journal of Operations Research, 20(1), 161-182. DOI: 10.1007/s10100-010-0186-z

Henrekson, M. (1993). Wagner's Law-A Spurious Relationship, Public Finance, 46(3), $406-$ 415.

Inigues-Montiel, A. J. (2010). Government expenditure and national income in Mexico: Keynes versus Wagner, Applied Economics Letters, 17(9), 887-893. DOI: $\underline{10.1080 / 13504850802599433}$

Islam, A. M. (2001). Wagner's Law revisited: Cointegration and exogeneity tests for the USA, Applied Economics Letters, 8(8), 509-515. DOI: 10.1080/13504850010018743

Iyare, S. O. \& Lorde, T. (2004). Co-integration, causality and Wagner's Law: tests for selected Caribbean countries, Applied Economics Letters, 11(13), 815-825. DOI: $\underline{10.1080 / 1350485042000254881}$

Johansen, S. \& Juselius, K. (1990). Maximum likelihood estimation and inference on cointegration with applications to the demand for Money, Oxford Bulletin of Economics and Statistics, 52(2), 169-210. DOI: 10.1111/i.14680084.1990.mp52002003.x

Kalu, I. E. \& James, O. E. (2012). Government expenditure and economic growth in Nigeria, 1980-2011, International Journal of Academic Research, 4(6), 204-208. DOI: 10.7813/2075-4124.2012/4-6/B.32

Kalam, M. A. \& Aziz, N. (2009). Growth of government expenditure in Bangladesh: An empirical enquiry into the validity of Wagner's Law, Global Economy Journal, 9(2), 1-20. DOI: 10.2202/1524-5861.1451

KargI, B. (2014). The effects of BRICS and MATIK counties on world economy and cointegration analysis the long term relation with G-7 growth rates (1962-2012), Journal of Economics and Behavioral Studies, 6(3), 262-272.

Khan, M. (2011). The Fall of The Wall, The Rise of The BRICs and The New Scramble for Africa. Foresight, 13(3), 38-49. DOI: 10.1108/14636681111138758

Kumar, S., Webber, D. J. \& Fargher, S. (2012). Wagner's Law revisited: Cointegration and causality tests for New Zealand, Applied Economics, 44(5), 607-616. DOI: $\underline{10.1080 / 00036846.2010 .511994}$

Kwiatkowski, D., Phillips, P. C. B., Schmidt, P., \& Shin, Y. (1992). Testing the Null Hypothesis of Stationary Against the Alternative of a Unit Root, Journal of Econometrics, 54(13), 159-178. DOI: 10.1016/0304-4076(92)90104-Y

Lamartina, S. \& Zaghini, A. (2010). Increasing public expenditure: Wagner's Law in OECD countries, German Economic Review, 12(2), 149-164. DOI: 10.1111/j.1468$\underline{0475.2010 .00517 . x}$

Liu, L. C-H., Hsu, C. E. and Younis, M. Z. (2008). The association between government expenditure and economic growth: Granger causality test of US data, 1947-2002, Journal of Public Budgeting, Accounting and Financial Management, 20(4), 537553.

Magazzino, C. (2012). Wagner versus Keynes: Public spending and national income in Italy, Journal of Policy Modeling, 34(6), 890-905. DOI: 10.1016/j.jpolmod.2012.05.012

Milesi Ferretti, G. M., Perotti, R. \& Rostagno, M. (2002). Electoral systems and public spending, Quarterly Journal of Economics, 117(2), 609-656. DOI: $\underline{10.1162 / 003355302753650346}$

Narayan, P. K., Prasad, A. \& Singh, B. (2008). A test of the Wagner's Hypothesis for the Fiji Islands, Applied Economics, 40(21), 2793-2801. DOI: 10.1080/00036840600972472 
Kargi, B. (2016).

Is Wagner's law applicable for fast growing economies? BRICS and MATIK countries

Narayan, P. K., Nielsen, I. \& Smyth, R. (2008). Panel data, cointegration, causality and Wagner's Law: Empirical evidence from Chinese provinces, China Economic Review, 19(2), 297-307. DOI: 10.1016/j.chieco.2006.11.004

Narayan, S., Rath, B. N. \& Narayan, P. K. (2012). Evidence of Wagner's Law from Indian $\begin{array}{llll}\text { states, } \quad \text { Economic } & \text { 1548-1557. Dodelling, }\end{array}$ 10.1016/i.econmod.2012.05.004

Oxley, L. (1994). Cointegration, causality and Wagner's law: a test for Britain, 1870-1913, Scottish Journal of Political Economy, 41(3), 286-298. DOI: 10.1111/j.14679485.1994.tb01127.x

Pesaran, M. H. \& Shin, Y. (1999). An autoregressive distributed lag modelling approach to cointegration analysis, in Econometrics and Economic Theory in the Increasing Public Expenditure 20th Century: The Ragnar Frisch Centennial Symposium, (Eds) S. Storm, Cambridge University Press, Cambridge, pp.371-413.

Phillips, P. C. B. \& Perron, P. (1988). Testing for an unit root in time series regression, Biometrika, 75(2), 335-346. DOI: 10.1093/biomet/75.2.335

Ram, R. (1986). Causality between income and government expenditure: a broad international perspective, Public Finance, 41(3), 393-414.

Ram, R. (1987). Wagner's hypothesis in time series and cross-section perspectives: evidence from 'real' data for 115 countries, Review of Economics and Statistics, 69(2), 194204. DOI: $10.2307 / 1927226$

Rodrik, D. (1998). Why do more open economies have bigger governments?, Journal of Political Economy, 106(5), 997-1032. DOI: 10.1086/250038

Roubini, N. \& Sala-i-Martin, X. (1995). A growth model of inflation, tax evasion, and financial repression, Journal of Monetary Economics, 35(2), 275-301. DOI: 10.1016/03043932(95)01192-Q

Roy, A. G. (2009). Evidence on economic growth and government size, Applied Economics, 41(5), 607-614. DOI: 10.1080/00036840601007393

Rufael, Y. W. (2008). The Revenue-Expenditure Nexus: The experience of 13 African counties, African Development Review, 20(2), 273-283. DOI: 10.1111/i.14678268.2008.00185.x

Sakyi, D. (2013). On the implications of trade openness, foreign aid and democracy for Wagner's Law in developing countries: Panel data evidence from West African monetary zone (WAMZ), The Journal of Developing Area, 47(2), 319-339. DOI: 10.1353/ida.2013.0033

Samudram, M., Nair, M. \& Vaithilingam, S. (2009). Keynes and Wagner on government expenditures and economic development: The case of a developing economy, Empirical Economics, 36(3), 697-712. DOI: 10.1007/s00181-008-0214-1

Schmalz, S. \& Ebenau, M. (2012). After Neoliberalism? Brazil, India, and China in the Global Economic Crisis. Globalization, 9(4), 487-501. DOI: 10.1080/14747731.2012.699917

Singh, S. (2013). Future of Golden BRICS, Strategic Analysis. 37(4), 393-397. DOI: $\underline{10.1080 / 09700161.2013 .802513}$

Tang, C. F. (2008). Wagner's Law versus Keynesian Hypothesis: New evidence from recursive regression-based causality approaches, ICFAl Journal of Public Finance, 6, 29-38.

Tang, C. F. (2010). Wagner's Law versus Keynesian Hypothesis in Malaysia: An impressionistic view, International Journal of Business and Society, 11, 87-96.

Thornton, J. (1999). Cointegration, causality and Wagner's Law in $19^{\text {th }}$ Century Europe, Applied Economics Letters, 6(7), 413-416. DOI: 10.1080/135048599352916 
Kargi, B. (2016).

Is Wagner's law applicable for fast growing economies? BRICS and MATIK countries

Turnovsky, S. (1997). Fiscal policy in a growing economy with public capital, Macroeconomic Dynamics, 1(3), 615-639. DOI: 10.1017/S1365100597004045

Wahab, M. (2004). Economic growth and government expenditure: evidence from a new test specification, Applied Economics, 36(19), 2125-2135. DOI: $\underline{10.1080 / 0003684042000306923}$

Wu, A. M., \& Lin, M. (2012). Determinants of government size: Evidence from China, Public Choice, 151(1), 255-270. DOI: 10.1007/s11127-010-9746-y

Yao, X. N. \& Liu, J. Y. (2011). The Potential of Economic Growth and Technology Advancement in The BRICS, Proceedings of The 2011, International Conference on Machine Learning and Cybernetics, pp.1067-1071, 10-13 July, Guilin.

Zaman, K., Khan, M. M., Ahmad, M. \& Khilii, B. A. (2011). Growth, employment, exports and Wagner's Law: Evidence from Pakistan's agriculture sector (1960-2009), International Journal of Rural Management, 7(1-2), 27-41. DOI: 10.1177/0973005212459825 